\section{Modulation of transforming growth factor $\beta$ function in hepatocytes and hepatic stellate cells in rat liver injury}

\author{
M Date, K Matsuzaki, M Matsushita, Y Tahashi, F Furukawa, K Inoue
}

Third Department of Internal Medicine, Kansai Medical University, 10-15 Fumizonocho, Moriguchi, Osaka 570-8507, Japan M Date

K Matsuzaki M Matsushita Y Tahashi F Furukawa K Inoue

Correspondence to: K Matsuzaki. Email: matsuzak@takii.kmu.ac.jp

Accepted for publication 3 November 1999

\begin{abstract}
Background-Transforming growth factor $\beta(\mathrm{TGF}-\beta)$ regulates hepatocyte proliferation and biosynthesis of the extracellular matrix.

Aims-This study investigated alternations in sensitivity to TGF- $\beta 1$ and binding properties for ligand in hepatocytes and hepatic stellate cells (HSC) after $\mathbf{C C l}_{4}$ administration.

Methods-Plasma TGF- $\beta 1$ levels in rats after $\mathbf{C C l}_{4}$ administration were determined using ELISA. Effects of TGF- $\beta 1$ were examined by DNA synthesis in hepatocytes and by measurement of fibronectin production in $\mathrm{HSC}$ after $\mathbf{C C l}_{4}$ administration. Binding of ${ }^{125}$ I TGF- $\beta 1$ was tested in these cells.

Results-Plasma TGF- $\beta 1$ levels were increased as early as 24 hours and were maximal by 48 hours. The antiproliferative response to TGF- $\beta 1$ decreased in hepatocytes at 48 hours and normalised at 72 hours. Fibronectin production of both normal and injured HSC was affected by TGF- $\beta 1$ treatment. Cross linked ligand/ receptor complexes were detected in normal hepatocytes and HSC. However, these levels decreased specifically in hepatocytes at 48 hours and normalised by 72 hours. Conclusions-Downregulation of TGF- $\beta$ receptor occurred in hepatocytes after chemical insult and TGF- $\beta 1$ could not transduce its antiproliferative signal. Recovery of TGF- $\beta$ receptor expression causes the signal to transduce to the nucleus at 72 hours. In HSC, whenever TGF- $\beta 1$ is increased, TGF- $\beta 1$ can transduce its signal for fibronectin production via its receptor because signalling receptors are expressed constantly.

(Gut 2000;46:719-724)
\end{abstract}

Keywords: TGF- $\beta$ receptor; liver regeneration; fibronectin; hepatocyte; hepatic stellate cell

The transforming growth factor $\beta$ (TGF- $\beta$ ) proteins are a family of multifunctional cytokines that regulate many aspects of cellular function and consequently have diverse effects on a variety of cell types and tissues. Although five highly homologous types of TGF- $\beta$ have been characterised, only the first three isoforms are found in mammals. ${ }^{12}$

TGF- $\beta$ elicit their effects by binding to cell surface receptors. Three major types of TGF- $\beta$ binding proteins are known to be widely distributed in most TGF- $\beta$ responsive cells. They are referred to as TGF- $\beta$ type I (T $\beta R I)$, type II (T $\beta$ RII), and type III (or $\beta$-glycan) (T $\beta$ RIII) receptors. T $\beta R I$ and $T \beta R I I$ are glycoproteins of 53 and $75 \mathrm{kDa}$, respectively, whereas T $\beta$ RIII is a proteoglycan of 280 $330 \mathrm{kDa} .^{3-5} \mathrm{~T} \beta \mathrm{RI}$ and T $\beta$ RII possess an extracellular region, a single transmembrane portion, and a serine/threonine kinase domain in the cytoplasmic region. T $\beta R I I$ can bind free ligand whereas T $\beta R I$ can only recognise ligand that is already bound with TßRII, and formation of a ligand induced heterotetramer involving both T $\beta R I$ and T $\beta R I I$ is required for signalling. In contrast, T $\beta R I I I$ lacks a cytoplasmic protein kinase domain and appears to function mainly in the concentration and presentation of TGF $\beta$ to T $\beta$ RI and T $\beta$ RII. ${ }^{6}$ Signalling by these receptors is mediated by the recently identified Smad protein family.

TGF- $\beta 1$ appears to be an important regulator in both normal and pathological conditions in the liver. ${ }^{8}$ TGF- $\beta 1$ is synthesised in nonparenchymal cells such as hepatic stellate cells (HSC) $^{9}$ and inhibits hepatocellular DNA synthesis both in culture and in vivo. Picomolar concentrations of TGF- $\beta 1$ suppress hepatocyte DNA synthesis in culture. ${ }^{10}$ Moreover, injection of TGF- $\beta 1$ into partially hepatectomised rats significantly delays the onset of DNA synthesis. ${ }^{11}$ In addition, TGF- $\beta 1$ increases the synthesis and deposition of extracellular matrix (ECM) proteins such as fibronectin by HSC and is closely associated with the progression of hepatic fibrosis. ${ }^{8} 12$

The level of DNA synthesis in parenchymal hepatocytes and mRNA expression of fibronectin and TGF- $\beta 1$ in non-parenchymal cells are maximal approximately 48 hours after acute $\mathrm{CCl}_{4}$ intoxication. ${ }^{9}{ }^{13-15}$ However, these results raise the question of why maximal levels of DNA synthesis are seen when the level of TGF- $\beta 1$, which inhibits hepatocyte proliferation, is already elevated and ECM is produced by non-parenchymal cells such as HSC. To answer this question, in a previous report we analysed expression of TGF- $\beta$ and its receptor mRNAs in both hepatocytes and nonparenchymal cells after $\mathrm{CCl}_{4}$ administration. ${ }^{15}$

Abbreviations used in this paper: DMEM,

Dulbecco's modified Eagle medium; ECM extracellular matrix; FCS, fetal calf serum; HGF, hepatocyte growth factor; HSC, hepatic stellate cells; PAGE, polyacrylamide gel electrophoresis; SDS, sodium dodecyl sulphate; TGF- $\beta$, transforming growth factor $\beta$; T $\beta$ RI, T $\beta$ RII, T $\beta$ RIII, TGF- $\beta$ type I, II, and III receptors. 
The results showed that there is downregulation of TGF- $\beta$ receptor $m R$ NAs in hepatocytes but that levels remain high in non-parenchymal cells after $\mathrm{CCl}_{4}$ administration. However, it is currently unclear if the cell type specific changes in mRNA expression reflect the abilities of TGF- $\beta$ receptors to bind ligand and TGF- $\beta$ signal. Therefore, in this study we focused our efforts on alternations in the sensitivity to TGF- $\beta 1$ and binding properties for ligand in both hepatocytes and HSC after $\mathrm{CCl}_{4}$ administration.

\section{Materials and methods \\ ANIMALS}

Eight to nine week old, 200-300 g male Wistar rats were obtained from Oriental Bio Service Co. (Kyoto, Japan) and were used in all experiments. All procedures were carried out in accordance with the Declaration of Helsinki and Guiding Principles on the Care and Use of Animals. For studies of liver regeneration after toxic injury, rats were given a single intragastric dose of $0.5 \mathrm{ml}$ of a $1: 1(\mathrm{v} / \mathrm{v})$ mixture of $\mathrm{CCl}_{4}$ in olive oil per $100 \mathrm{~g}$ body weight. These animals were sacrificed at $0,24,48,72$, and 96 hours after administration of the agent. Blood was collected into heparinised syringes at sacrifice, and plasma samples were stored at $-80^{\circ} \mathrm{C}$ until use.

MEASUREMENT OF TGF- $\beta 1$ BY ELISA

To determine the concentration of TGF- $\beta 1$ in rat plasma after $\mathrm{CCl}_{4}$ administration, we used an enzyme-linked immunoassay kit for human TGF- $\beta 1$ (R\&D Systems Inc., Minneapolis, Minnesota, USA) that cross reacts with the rat protein. Values are expressed in $\mathrm{ng} / \mathrm{ml}$ with a lower limit of detection of $0.005 \mathrm{ng} / \mathrm{ml}$.

CELL SEPARATION PROCEDURE

Hepatocytes and HSC were isolated from normal rat liver or rat liver injured at 48 and 72 hours after $\mathrm{CCl}_{4}$ administration. HSC were obtained using collagenase and pronase-E digestion according to the modified method of Knook and colleagues. ${ }^{16}$ The liver was perfused in a non-circulating system for two minutes at $37^{\circ} \mathrm{C}(40 \mathrm{ml} / \mathrm{min})$. The perfusion solution was calcium free Hanks buffer $(137 \mathrm{mM} \mathrm{NaCl}, 5.4$ $\mathrm{mM} \mathrm{KCl}, 0.5 \mathrm{mM} \mathrm{NaH} \mathrm{PO}_{4}, 0.42 \mathrm{mM}$ $\mathrm{Na}_{2} \mathrm{HPO}_{4}, 5 \mathrm{mM}$ glucose, $25 \mathrm{mM} \mathrm{NaHCO}, 10$ $\mathrm{mM}$ HEPES, and $0.5 \mathrm{mM}$ EGTA at $\mathrm{pH}$ 7.2-7.3). The livers were then circulated with the perfusion solution for five minutes. A solution $(200 \mathrm{ml})$ consisting of $0.1 \%$ collagenase (Wako, Osaka, Japan) in $10 \mathrm{mM}$ HEPES, $\mathrm{pH}$ 7.5, with $5 \mathrm{mM}$ calcium without EGTA was recirculated for 5-10 minutes. The liver was cut into pieces and incubated in $100 \mathrm{ml}$ of Gey's balanced salt solution with $0.1 \%$ pronase-E (Sigma, St Louis, Missouri, USA) on a magnetic stirrer at $37^{\circ} \mathrm{C}$ for 30 minutes. At the end of the incubation period, the suspension was filtered through Nylon gauze and the filtrate was centrifuged at $450 \mathrm{~g}$ for seven minutes. The collected cells were centrifuged on a two layer density cushion of Nycodenz (Nycomed, Oslo, Norway) (Gey's balanced salt solution $/ 8 \%$ Nycodenz) at $1400 \mathrm{~g}$ for 17 minutes. The HSC fraction was collected from the upper layer. The purity of the HSC was greater than $90 \%$, as assessed by typical morphological features and the immunological staining of desmin. Hepatocytes were prepared by perfusion of the liver in situ with collagenase and purified by centrifugal elutriation as previously described. ${ }^{15}$

\section{LIVER CELL CULTURE}

Purified cells were kept in culture at $37^{\circ} \mathrm{C}$ in a $5 \% \quad \mathrm{CO}_{2}$ atmosphere and $100 \%$ humidity. Hepatocytes were cultured in Williams' medium $\mathrm{E}$ supplemented with $5 \%$ fetal calf serum (FCS), $10 \mathrm{nM}$ dexamethazone, 100 units $/ \mathrm{ml}$ penicillin $\mathrm{G}$, and $0.1 \mathrm{mg} / \mathrm{ml}$ streptomycin. HSC were cultured in Dulbecco's modified Eagle's medium (DMEM) supplemented with 5\% FCS, 100 units $/ \mathrm{ml}$ penicillin $\mathrm{G}$, and 0.1 $\mathrm{mg} / \mathrm{ml}$ streptomycin.

\section{ASSAY OF DNA SYNTHESIS}

The isolated hepatocytes were suspended in culture medium at $1 \times 10^{5} \mathrm{cells} / \mathrm{ml}$ and seeded into 24 well dishes $(0.5 \mathrm{ml} /$ dish). After two hours the medium was changed to serum free Williams' medium E. Various concentrations of porcine TGF- $\beta 1$ (R\&D Systems Inc.) with or without $10 \mathrm{ng} / \mathrm{ml}$ of recombinant human hepatocyte growth factor (HGF) (R\&D Systems Inc.) were added to the medium 12 hours after seeding. After further incubation for 24 hours, $2 \mu \mathrm{Ci} /$ well of $\left[\right.$ methyl- $\left.{ }^{3} \mathrm{H}\right]$ thymidine $(25 \mathrm{Ci} /$ mmol; Amersham, Buckinghamshire, UK) were added to the medium and culture was continued for three hours. At the end of the pulsing period, the medium was carefully aspirated, icecold 5\% trichloroacetic acid was added, and dishes were kept on ice for $15 \mathrm{~min}$ utes. After two additional washes with 5\% trichloroacetic acid, cells were solubilised by adding $500 \mu \mathrm{l}$ of $0.5 \mathrm{~N} \mathrm{NaOH}$. The solubilised cell solution $(250 \mu \mathrm{l})$ was then neutralised with $0.5 \mathrm{~N} \mathrm{HCl}(250 \mu \mathrm{l})$ and radioactivity $(\mathrm{cpm})$ measured in a liquid scintillation counter.

MEASUREMENT OF FIBRONECTIN PRODUCTION Fibronectin production was measured as described, with minor modifications. ${ }^{17}$ The isolated HSC were suspended in culture medium at $2 \times 10^{5}$ cells $/ \mathrm{ml}$ and seeded into 12 well dishes. After two hours the medium was changed to fresh culture medium containing $0.2 \% \mathrm{FCS}$. After five hours the cells were incubated with or without various concentrations of TGF- $\beta 1$ for 20 hours and labelled with $50 \mu \mathrm{Ci}$ of a $\left[{ }^{35} \mathrm{~S}\right]$ methionine and $\left[{ }^{35} \mathrm{~S}\right]$ cysteine mixture (Pro-mix cell labelling mix: Amersham) in $1 \mathrm{ml}$ of methionine and cysteine free DMEM (ICN Pharmaceuticals, Costa Mesa, California, USA) for the final four hours. Labelled culture media $(1 \mathrm{ml})$ were collected and labelled fibronectin was purified by absorption to $100 \mu \mathrm{l}$ of gelatin-sepharose (Pharmacia, Uppsala, Sweden) in the presence of $0.5 \%$ Triton X-100. The beads were washed once in Tris buffered saline $(50 \mathrm{mM}$ Tris $\mathrm{HCl}, \mathrm{pH} 7.4,150 \mathrm{mM}$ $\mathrm{NaCl}$ ), once in $50 \mathrm{mM}$ Tris $\mathrm{HCl}(\mathrm{pH} \mathrm{7.4}), 0.5$ $\mathrm{M} \mathrm{NaCl}$, and once in Tris buffered saline. Fibronectin was eluted by boiling in sodium 
dodecyl sulphate (SDS) sample buffer in the presence of $10 \mathrm{mM}$ dithiothreitol. The samples were analysed by $7 \%$ SDS-polyacrylamide gel electrophoresis (PAGE) and autoradiography. Relative amounts of fibronectin were quantified by densitometric scanning.

BINDING AND COVALENT AFFINITY CROSS LINKING OF LIGAND

Carrier free TGF- $\beta 1$ was iodinated to a specific activity of $1 \times 10^{5} \mathrm{cpm} / \mathrm{ng}(25 \mu \mathrm{Ci} / \mathrm{ng})$ by the chloramine $\mathrm{T}$ method as previously described. ${ }^{18}$ The isolated hepatocytes and HSC were suspended in culture medium at $3 \times 10^{6}$ cells $/ \mathrm{ml}$ and seeded onto $10 \mathrm{~cm}$ dishes. After three hours, cell monolayers were incubated for one hour at $4^{\circ} \mathrm{C}$ with $200 \mathrm{pM}{ }^{125} \mathrm{I}$ labelled TGF- $\beta 1$ alone or with excess (5 nM) unlabelled TGF- $\beta 1$. Receptors were cross linked to bound ligand with disuccinimidyl suberate and solubilised in the presence of Triton X-100 as previously described. ${ }^{19}$ Cell extracts were clarified by centrifugation and then subjected to $7 \%$ SDS-PAGE and autoradiography.

STATISTICAL ANALYSIS

Data are expressed as mean (SD). Experimental and control values were compared using the unpaired Student's $t$ test and ANOVA; $\mathrm{p}<0.05$ was considered significant.

\section{Results}

ELEVATION OF TGF- $\beta 1$ LEVEL IN RAT PLASMA AFTER CCL $_{4}$ ADMINISTRATION

Using northern blot hybridisation we observed approximately fivefold induction of TGF- $\beta 1$ mRNA in regenerating livers at 48 hours after $\mathrm{CCl}_{4}$ administration. ${ }^{915}$ To determine if protein levels also increased we measured TGF- $\beta 1$ protein by ELISA in rat plasma after $\mathrm{CCl}_{4}$ administration. Figure 1 illustrates the results of plasma TGF- $\beta 1$ measurements after $\mathrm{CCl}_{4}$ administration. Plasma levels of TGF- $\beta 1$ were increased as early as 24 hours and were maximal by 48 hours, reaching five times that in normal plasma and decreasing thereafter.

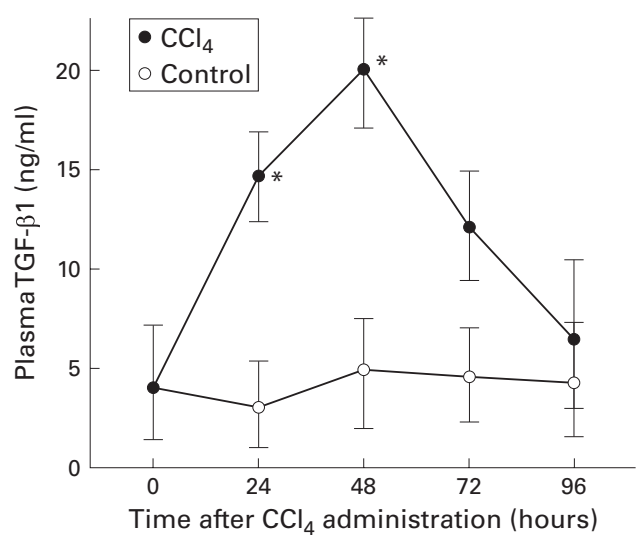

Figure 1 Quantitative analysis of plasma transforming growth factor $\beta 1$ (TGF- $\beta 1$ ) protein after $C C l$ administration by enzyme linked immunoassay. Plasma samples were collected from normal and injured rats at the indicated times after $\mathrm{CCl}_{4}$ administration and stored at $-80^{\circ} \mathrm{C}$. Data are expressed as mean (SD) for triplicate determinations in $\mathrm{CCl}_{4}$ treated and control rats. ${ }^{\star} p<0.05$ control.
Plasma levels of TGF- $\beta 1$ were essentially unchanged in the rat treated only with olive oil at various times between 24 and 96 hours. Consistent with mRNA induction, TGF- $\beta 1$ protein was induced in the injured liver. These results suggest that elevated levels of TGF- $\beta 1$ have potential roles in liver regeneration and ECM production. Therefore, we studied the time dependent differential sensitivity of individual liver cell types to the growth inhibitory effect of TGF- $\beta 1$ and its induction of ECM expression.

DIFFERENTIAL ANTIPROLIFERATIVE RESPONSE OF TGF- $\beta 1$ ON HEPATOCYTES AFTER CCL $_{4}$ ADMINISTRATION

First we examined if TGF- $\beta 1$ induced by liver injury affected hepatocyte growth. The effect of TGF- $\beta 1$ on cellular proliferation was studied by measuring $\left[\right.$ methyl $\left.-{ }^{3} \mathrm{H}\right]$ thymidine incorporation into the DNA of hepatocytes. Figure 2 shows the effects of TGF- $\beta 1$ on DNA synthesis of normal hepatocytes in the presence or absence of exogenous HGF. HGF induced a fivefold increase in DNA synthesis of hepatocytes. TGF- $\beta 1$ inhibited DNA synthesis of hepatocytes not only in the absence but also in the presence of exogenous $\mathrm{HGF}$ in a dose dependent manner in the range $1-10^{4} \mathrm{pg} / \mathrm{ml}$, consistent with previous reports. ${ }^{20}$ This effect was half maximal with approximately $10 \mathrm{pg} / \mathrm{ml}$ TGF- $\beta 1$.

It is not clear why maximal levels of DNA synthesis are observed at 48 hours in spite of the increased levels of TGF- $\beta 1$ which inhibit hepatocyte proliferation. To determine this we monitored the sensitivity of hepatocytes to the growth inhibitory effect of TGF- $\beta 1$ after $\mathrm{CCl}_{4}$ administration and compared DNA synthesis of normal liver in the presence of TGF- $\beta 1$ with that of injured liver. In the presence of 10 $\mathrm{pg} / \mathrm{ml}$ TGF- $\beta 1$, HGF induced DNA synthesis in normal hepatocytes was reduced to approximately $50 \%$. This inhibitory effect of TGF- $\beta 1$ was decreased to approximately $20 \%$

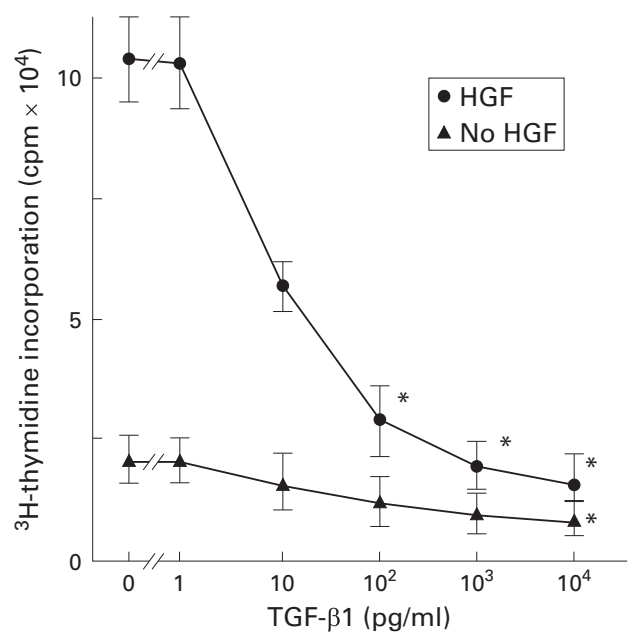

Figure 2 Effect of transforming growth factor $\beta 1$ (TGF- $\beta 1$ ) on DNA synthesis of cultured hepatocytes. Experimental conditions were as described in the text. Various concentrations of TGF- $\beta 1$ were added as indicated in the absence or presence of exogenous hepatocyte growth

factor $(H G F)(10 \mathrm{ng} / \mathrm{ml})$. Data are expressed as mean (SD) of triplicate determinations. ${ }^{\star} p<0.05 v$ control. 


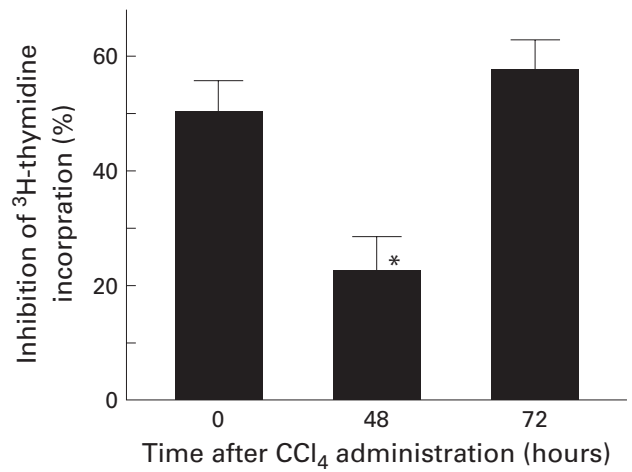

Figure 3 Time dependent differential sensitivity of hepatocytes to the growth inhibitory effect of transforming growth factor $\beta 1$ (TGF- $\beta 1$ ) after $C_{C l}$ administration. growth factor $\beta 1$ (TGF- $\mathrm{T}$ - $\beta 1$ ) after $\mathrm{CCl}_{4}$ administration.
Here isolated from normal rat liver or rat liver injured at 48 and 72 hours after $\mathrm{CCl}_{4}$ administration. The hepatocytes were subjected to a $\beta \mathrm{H}]$ thymidine assay in the presence of $10 \mathrm{pg} / \mathrm{ml}$ of TGF- $\beta 1$ and $10 \mathrm{ng} / \mathrm{ml}$ of hepatocyte growth factor (HGF). The percentage of growth inhibition was calculated by measuring the decrease relative to $\left.{ }^{3} \mathrm{H}\right]$ thymidine incorporation into cells in the absence of $T G F-\beta 1$. Data are expressed as mean (SD) for triplicate determinations. ${ }^{*} p<0.05 v$ control.

in hepatocytes at 48 hours after $\mathrm{CCl}_{4}$ administration and returned to normal levels at 72 hours (fig 3). These results indicated that hepatocytes at 48 hours after chemical insults showed a reduced response to growth inhibition by TGF- $\beta 1$.

STIMULATION OF FIBRONECTIN PRODUCTION BY TGF- $\beta 1$ IN HSC AFTER $\mathrm{CCl}_{4}$ ADMINISTRATION At the regenerating stage of the liver, hepatocytes seemed to be resistant to TGF- $\beta 1$ stimuli although the protein level of TGF- $\beta 1$ was already increased. However, this leads to the question of whether the elevated TGF- $\beta 1$ has other biological effects on non-parenchymal cells. In addition, TGF- $\beta 1$ increased synthesis and deposition of ECM proteins in many mesenchymal cells. $^{1{ }^{2}}$ Therefore, we next examined ECM production from non-parenchymal cells. We used HSC because of the central importance

A
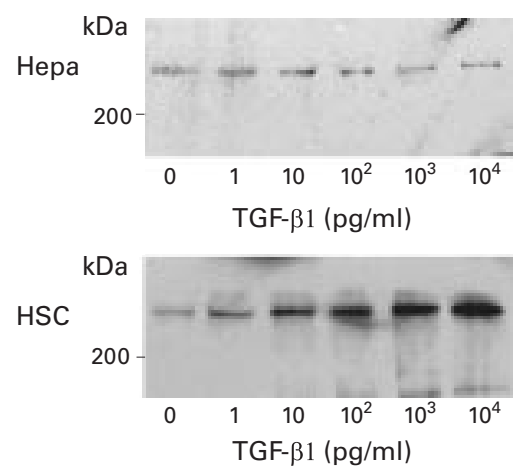

\section{B}

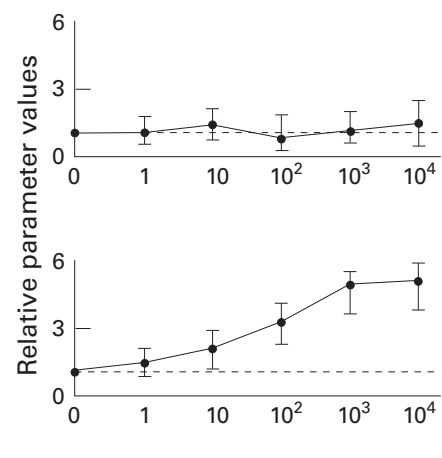

Figure 4 Fibronectin production induced by transforming growth factor $\beta 1$ (TGF- $\beta 1$ ) in hepatocytes (Hepa) and hepatic stellate cells (HSC). Cells were incubated with culture medium for five hours. Cells were then incubated with various concentrations of TGF- $\beta 1$ for 20 hours and labelled with a ${ }^{35} S /$ methionine and $\left.{ }^{35} S\right]$ cysteine mixture for the last four hours. Fibronectin secreted into media was purified by adsorption to gelatin-Sepharose, analysed by $7 \%$ SDS-PAGE, and visualised by autoradiography. This figure is representative of three separate experiments $(A)$. Changes in expression of fibronectin were quantitated by densitometry $(B)$. The values shown are the mean of results from three separate experiments. Fibronectin expression in untreated cells was assigned a value of 1 and other values expressed relative to this were plotted against the concentration of exogenous TGF- $\beta 1$. The horizontal broken line indicates the control value.
A

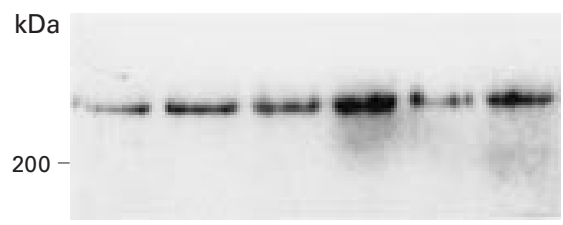

B

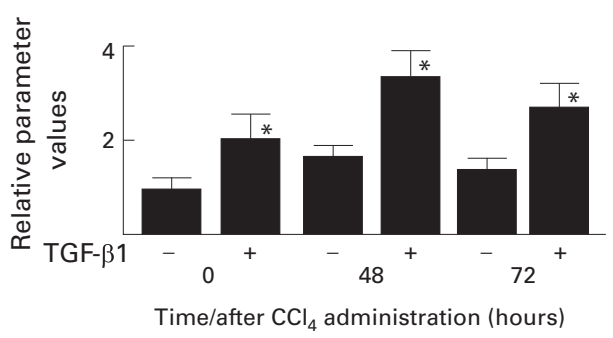

Figure 5 Time dependent differential sensitivity of hepatic stellate cells (HSC) to the effect produced by transforming growth factor $\beta 1$ (TGF- $\beta 1$ ) after $C C l_{4}$ administration. HSC were isolated from normal rat liver or rat liver injured at 48 and 72 hours after $C C l$

administration. HSC were subjected to fibronectin assay in the absence or presence of $100 \mathrm{pg} / \mathrm{ml}$ of TGF- $\beta 1$. Fibronectin secreted into the media was purified by adsorption to gelatin-sepharose, analysed by $7 \%$

SDS-PAGE, and visualised by autoradiography. This figure is representative of three separate experiments $(A)$. Changes in expression of fibronectin were quantitated by densitometry (B). For each culture condition the relative expression in untreated normal HSC was assigned a value of 1. Data are expressed as mean (SD) for triplicate determinations. ${ }^{\star} p<0.05 v$ control.

for ECM production and liver fibrosis. ${ }^{21}$ Furthermore, we examined fibronectin production because fibronectins are major components in the liver and representative of the various matrix proteins induced by TGF- $\beta 1 .^{22}$

To examine if TGF- $\beta 1$ induced the production of fibronectin in hepatocytes and HSC, a fibronectin assay was performed by measuring incorporation of $\left[{ }^{35} \mathrm{~S}\right]$ methionine and $\left[{ }^{35} \mathrm{~S}\right]$ cysteine into fibronectin. The production of fibronectin in HSC, but not in hepatocytes, was induced dose dependently by TGF- $\beta 1$ (fig $4 \mathrm{~A})$. The resulting changes in the expression of fibronectin shown in fig $4 \mathrm{~A}$ are graphically represented in fig $4 \mathrm{~B}$. This effect in HSC was half maximal with approximately $100 \mathrm{pg} / \mathrm{ml}$ TGF- $\beta 1$.

The sensitivity of HSC to TGF- $\beta 1$ at 48 hours after chemical insult needs to be studied because hepatocyte growth is resistant to TGF- $\beta 1$ at this time. Therefore, we compared fibronectin production of normal HSC in the presence of TGF- $\beta 1$ with that of HSC after $\mathrm{CCl}_{4}$ administration (fig 5). The level of fibronectin was already elevated in activated HSC after $\mathrm{CCl}_{4}$ administration. However, similar to normal HSC, $100 \mathrm{pg} / \mathrm{ml}$ TGF- $\beta 1$ stimulated fibronectin production in HSC at 48 hours when hepatocytes, after chemical insult, showed a reduced response to growth inhibition by TGF- $\beta 1$. This indicated that fibronectin production of $\mathrm{HSC}$ after $\mathrm{CCl}_{4}$ administration was also affected by TGF- $\beta 1$ treatment. The resulting changes in the expression of fibronectin shown in fig 5A are graphically represented in fig $5 \mathrm{~B}$. 
A

B

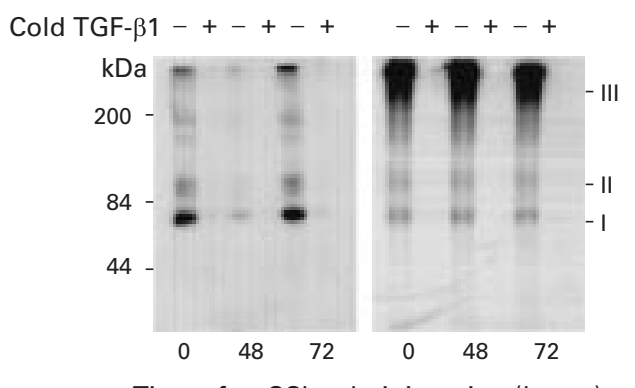

Time after $\mathrm{CCl}_{4}$ administration (hours)

Figure 6 Time dependent differential binding of ${ }^{125} I$ transforming growth factor $\beta 1$ (TGF- $\beta 1$ ) for the receptors on hepatocytes (A) and hepatic stellate cells (HSC) (B) after $\mathrm{CCl}_{4}$ administration. Cells were isolated from normal rat liver or rat liver injured at 48 and 72 hours after $\mathrm{CCl}_{4}$ administration. Cells were affinity labelled with 200 pM of ${ }^{125} I T G F-\beta 1$ in the absence or presence of $5 n M$ unlabelled (cold) TGF- $\beta 1$. Labelled proteins were separated by SDS-PAGE and visualized by autoradiography. This figure is representative of three separate experiments.

DIFFERNTIAL BINDING OF ${ }^{125}$ I TGF- $\beta 1$ TO THE RECEPTORS ON HEPATOCYTES AND HSC AFTER $\mathrm{CCl}_{4}$ ADMINISTRATION

In contrast with the small antiproliferative response to TGF- $\beta 1$ on hepatocytes during liver regeneration, the sensitivity of HSC for fibronectin production by TGF- $\beta 1$ was not affected after chemical insult. To pursue the possible mechanisms of these differences, we focused our efforts on the affinities of the ligand to the receptors in both hepatocytes and HSC after $\mathrm{CCl}_{4}$ administration. To test TGF- $\beta$ receptor for the ability to bind ligand in hepatocytes (fig 6A) and $\mathrm{HSC}$ (fig 6B) after $\mathrm{CCl}_{4}$ administration, ${ }^{125} \mathrm{I}$ TGF- $\beta 1$ was cross linked to these cells using the homobifunctional cross linker disuccinimidyl suberate. ${ }^{125} \mathrm{I}$ TGF- $\beta 1$ bound to three different proteins in normal HSC with molecular weights of approximately 65,85 , and $300 \mathrm{kDa}$, which disappeared on addition of an excess of unlabelled TGF- $\beta 1$. From the molecular weights, the three proteins appear to represent ${ }^{125} \mathrm{I}$ TGF- $\beta 1-T \beta R I,{ }^{125} \mathrm{I}$ TGF- $\beta 1-T \beta R I I$, and ${ }^{125} \mathrm{I}$ TGF- $\beta 1-T \beta R I I I$ complexes, respectively. ${ }^{125} \mathrm{I}$ TGF- $\beta 1-\mathrm{T} \beta \mathrm{RI}$ and ${ }^{125}$ I TGF- $\beta 1$-T $\beta$ RII complexes were observed in normal hepatocytes as well as HSC. However, ${ }^{125}$ I TGF- $\beta 1$-T $\beta$ RIII complexes were scarcely detected. At 48 hours after $\mathrm{CCl}_{4}$ administration, T $\beta \mathrm{RI}$ and T $\beta \mathrm{RII}$ in hepatocytes interacted very weakly with ligand. Then, the ability of two TGF- $\beta$ receptors to bind ligand recovered, reaching normal levels at 72 hours. Our results using a receptor cross linking assay suggested that expression of T $\beta R I$ and T $\beta$ RII was depressed specifically in hepatocytes at 48 hours after $\mathrm{CCl}_{4}$ administration. Unlike in hepatocytes, the ability of T $\beta R I$ and T $\beta$ RII to bind ligand did not decrease in HSC during treatment.

\section{Discussion}

In this present study we addressed the important question of the role of TGF- $\beta$ in regulating cell proliferation and ECM synthesis following rat liver injury. We have reported previously that the levels of T $\beta R I$ and T $\beta R I I$ mRNA expression in rat hepatocytes decreased from 12 to 48 hours and returned to normal by 72 hours after $\mathrm{CCl}_{4}$ administration while T $\beta \mathrm{RI}$ and T $\beta$ RII mRNA were expressed constantly in non-parenchymal cells. ${ }^{15}$ These results were consistent with the change in binding of ${ }^{125} \mathrm{I}$ TGF- $\beta 1$ to the receptors on hepatocytes and HSC after $\mathrm{CCl}_{4}$ administration. At 48 hours after $\mathrm{CCl}_{4}$ administration, T $\beta \mathrm{RI}$ and T $\beta \mathrm{RII}$ in hepatocytes interacted very weakly with ligand. Our results indicated that there is a transient downregulation of TGF- $\beta$ receptor proteins in the hepatocytes following $\mathrm{CCl}_{4}$ administration.

TGF- $\beta$ is known to be the most potent growth inhibitor for a wide variety of cell types, including hepatocytes. ${ }^{10}$ Our results showed that the inhibitory effect of TGF- $\beta 1$ decreased in hepatocytes at 48 hours after $\mathrm{CCl}_{4}$ administration and returned to normal level at 72 hours. Consistent with downregulation of the mitoinhibitory effect, DNA synthesis in hepatocytes reached a peak at 48 hours after $\mathrm{CCl}_{4}$ administration. This result raises the possibility that downregulation of the mitoinhibitory effect of TGF- $\beta 1$ enhances the effect of mitogenic factor induced by chemical insult. During the proliferative phase, there is an inverse correlation between expression of the TGF- $\beta$ receptor and DNA synthesis in hepatocytes. These observations suggest that by decreasing receptor expression, TGF- $\beta 1$ cannot transduce its antiproliferative signal via TGF- $\beta$ receptors on hepatocytes. Furthermore, return of receptor expression to a normal level in the later stages of regeneration may account for the return in hepatocyte sensitivity to TGF- $\beta$ and may be involved in limiting hepatocyte proliferation once the liver has regenerated.

Although the mechanism of reduction of TGF- $\beta$ receptor transcripts is currently unknown, several reports analysed the promoter region of T $\beta$ RII to pursue the transcriptional mechanism of this gene. Bae et al identified two positive regulatory elements and at least one negative regulatory element in the promoter region of T $\beta$ RII. ${ }^{23}$ Furthermore, Kim et al reported that an absolute reduction of T $\beta$ RII mRNA followed by transformation of keratinocytes with E1A oncogene is the result of decreased expression of unidentified transcription factor complexes that interact with two positive regulatory elements. ${ }^{24}$ Therefore, we speculate that downregulation of T $\beta R I I$ in hepatocytes is caused by a decrease in these transcription factors.

Among the most striking effects of TGF- $\beta$ on cellular function in vitro is its promotion of extracellular formation. TGF- $\beta$ increases synthesis and deposition of extracellular components such as fibronectin and some forms of collagen. ${ }^{18}$ In the liver, HSC is an important effector of hepatic fibrosis. ${ }^{12}{ }^{21}$ Despite depression of TGF- $\beta$ receptor levels in hepatocytes, these levels remained constant in HSC in the liver injured by $\mathrm{CCl}_{4}$ treatment. In addition, TGF- $\beta 1$ stimulated the production of fibronectin even by injured HSC. These results suggest that TGF- $\beta 1$ induces many components of the ECM by an autocrine mechanism 
whenever TGF- $\beta 1$ is produced after $\mathrm{CCl}_{4}$ administration.

TGF- $\beta 1$ mRNA expression in nonparenchymal cells reaches a maximum at about 48 hours after $\mathrm{CCl}_{4}$ administration. ${ }^{9}{ }^{15}$ In addition, we report that plasma levels of TGF- $\beta 1$ are also increased as early as 24 hours after $\mathrm{CCl}_{4}$ administration and are maximal by 48 hours, returning to control levels after four days. However, the question of why the regulation of hepatocyte proliferation and promotion of ECM deposition occurred at the same time remains unanswered. Our present results confirmed a hypothesis concerning the action of TGF- $\beta 1$ in liver regeneration and ECM production. In HSC, TGF- $\beta 1$ can transduce its signal for ECM production via its receptor stably by an autocrine mechanism because signalling receptors are expressed constantly after $\mathrm{CCl}_{4}$ administration. In contrast, without the receptor, TGF- $\beta 1$ cannot bind to hepatocytes and block the DNA replication signal induced by mitogenic factor at 48 hours after $\mathrm{CCl}_{4}$ administration. Recovery of TGF- $\beta$ receptor expression in hepatocytes makes the antiproliferative signal transduce to the nucleus at 72 hours. Further analysis of TGF- $\beta$ signal transduction including as the Smad protein family in liver damaged by viruses or chemical toxicity will contribute to our understanding of the mechanism of liver regeneration and ECM production.

This study was supported by a grant-in-aid for scientific research from the Ministry of Education, Science, and Culture of Japan.

1 Massagué J. Transforming growth factor- $\beta$ family. Annu Rev Cell Biol 1990;6:597-641.

2 Barnard JA, Lyons RM, Moses HL. The cell biology of transforming growth factor $\beta$. Biochem Biophys Acta 1990;1032:79-87

3 Franzén $\mathrm{P}$, ten Dijke $\mathrm{P}$, Yamashita $\mathrm{H}$, et al. Cloning of a TGF $\beta$ type I receptor that forms a heteromeric complex with the TGF $\beta$ type II receptor. Cell 1993;75:681-92.

4 Lin HY, Wang X-F, Ng-Eaton E, et al. Expression cloning of the TGF $\beta$ type II receptor, a functional transmembrane serine/threonine kinase. Cell 1992;68:775-85.

5 Wang X-F, Lin HY, Ng-Eaton E, et al. Expression cloning and characterization of the TGF $\beta$ type III receptor. Cell 1991;67:797-805

6 Attisano L, Wrana JL, López-Casillas F, et al. TGF- $\beta$ receptors and actions. Biochem Biophys Acta 1994;1222:71-80.
7 Heldin C-H, Miyazono K, ten Dijke P. TGF- $\beta$ signalling from cell membrane to nucleus through SMAD proteins. Nature 1997;390:465-71.

8 Bedosa P, Paradis V. Transforming growth factor- $\beta$ (TGF$\beta)$ : a key-role in liver fibrogenesis. F Hepatol 1995;22:3742 .

9 Armendariz-Borunda J, Seyer JM, Kang AN, et al. Regulation of TGF $\beta$ gene expression in rat liver intoxicated with carbon tetrachloride. FASEB F 1990;4:215-21.

10 Carr BI, Hayashi I, Branum EL, et al. Inhibition of DNA synthesis in rat hepatocytes by platelet derived type $\beta$ synthesis in rat hepatocytes by platelet derived type
transforming growth factor. Cancer Res $1986 ; 46: 2330-4$.

11 Russell WE, Coffey RJ, Ouellette AJ, et al. Type $\beta$ transforming growth factor reversibly inhibits the early proliferative response to partial hepatectomy in the rat. Proc Natl Acad Sci USA 1988;85:5126-30.

12 Friedman SL. The cellular basis of hepatic fibrosis. Mechanisms and treatment strategies. $N$ Engl f Med 1993;328: $1828-35$.

13 Lindroos PM, Zarngar R, Michalopoulos GK. Hepatocyte growth factor (hepatoproietin) rapidly increases in plasma before DNA synthesis and liver regeneration stimulated before DNA synthesis and liver regeneration stimulated
partial hepatectomy and tetrachloride administration. Hepatology 1991;13:743-9.

14 Odenthal M, Neubauer K, Meyer zum Büschenfelde KH, et al. Localization and mRNA steady-state level of cellular fibronectin in rat liver undergoing a $\mathrm{CCl}_{4}$-induced acute damage or fibrosis. Biochem Biophys Acta 1993;1181:26672 .

15 Date M, Matsuzaki K, Matsushita M, et al. Differential expression of transforming growth factor- $\beta$ and its receptors in hepatocytes and nonparenchymal cells of rat
liver after $\mathrm{CCl}_{4}$ administration. F Hepatol 1998;28:572-81.

16 Knook DL, Seffelaar AM, De Leeuw AM. Fat storing cells of the rat liver. Their isolation and purification. Exp Cell Res 1982;139:468-71.

17 Saitoh M, Nishitoh H, Amagasa T, et al. Identification of important regions in the cytoplasmic juxtamembrane domain of type I receptor that separate signaling pathways transforming growth factor- $\beta$. F Biol Chem 1996;271:276975.

18 Matsuzaki K, Xu J, Wang F, et al. A widely expressed transmembrane serine/threonine kinase that does not bind activin, inhibin, transforming growth factor $\beta$, or bone morphogenic factor. F Biol Chem 1993;268:12719-23.

$19 \mathrm{Xu} \mathrm{J}$, McKeehan K, Matsuzaki K, et al. Inhibin antagonizes inhibition of liver cell growth by activin by a dominantnegative mechanism. F Biol Chem 1995;270:6308-13.

20 Nakamura T, Tomita Y, Hirai R, et al. Inhibitory effect of transforming growth factor- $\beta$ on DNA synthesis of adult rat hepatocytes in primary culture. Biochem Biophys Res Commun 1985;133:1042-50.

21 Hautekeete ML, Geerts A. The hepatic stellate (Ito) cell: its role in human liver disease. Virchows Arch 1997;430:195207.

22 Ramadori G, Knittel T, Odenthal M, et al. Synthesis of cellular fibronectin by rat liver fat-storing (Ito) cells: regulation by cytokines. Gastroenterology 1992;103:131321

23 Bae HW, Geiser AG, Kim DH, et al. Characterization of the promoter region of the human transforming growth factor- $\beta$ type II receptor gene. F Biol Chem 1995;270: 29460-8.

$24 \mathrm{Kim} \mathrm{DH}$, Chang $\mathrm{JH}$, Lee $\mathrm{KH}$, et al. Mechanism of E1A-induced transforming growth factor- $\beta$ (TGF- $\beta$ ) resistance in mouse keratinocytes involves repression of TGF- $\beta$ type II transcription. F Biol Chem 1997;272: 688-94. 